\title{
New data on taxonomy and systematics of the genus Diamesa Meigen (Diptera: Chironomidae: Diamesinae) from Tien Shan and Pamir Mountains, with description of two new species
}

\author{
Eugenyi A. MAKARCHENKO, ${ }^{1 *}$ Alexander A. SEMENCHENKO,${ }^{2}$ Dmitry M. PALATOV ${ }^{3}$
}

${ }^{1}$ Federal Scientific Center of the East Asia Terrestrial Biodiversity, Far East Branch of the Russian Academy of Sciences, 100 let Vladivostoku 159, 690022 Vladivostok; ${ }^{2}$ Far Eastern Federal University, Suhanova St. 8, 690950 Vladivostok; ${ }^{3}$ Lomonosov Moscow State University, 1-12 Leninskie Gory, 119992 Moscow, Russia

*Corresponding author: makarchenko@biosoil.ru

\begin{abstract}
An illustrated morphological description of two new species of the genus Diamesa Meigen, 1835 are provided from Tien Shan and Pamir mountains: $D$. akhrorovi sp. nov., as male adult; $D$. alibaevae sp. nov., as male adult and pupa. DNA barcoding results of the two new described species with comparative database on some related Diamesa species are also given. The two new described species key both near D. planistyla Reiss, 1968, which was known from Nepal and redescribed here from Tian Shan. The diversity of Diamesa genus using three mitochondrial (COI, COII, 16S rRNA), two nuclear (18S rRNA, EF-1a) markers and estimating phylogenetic relationships is also highlighted. Six of the studied Diamesa species including D. akhrorovi sp. nov. and D. alibaevae sp. nov. represent a well-supported monophyletic clades with high Bayesian posterior probability, while D. cinerella Meigen and D. hamaticornis Kieffer have a lower interspecific sequence divergence.
\end{abstract}

Key words: Chironomids; Diamesa; systematics; new species; barcoding; Tien Shan; Pamir.

Received: February 2018. Accepted: June 2018.

This paper was presented at the $20^{\text {th }}$ International Symposium on Chironomidae, Trento, Italy, 2-8 July 2017.

Session: Taxonomy and Systematics.

\section{INTRODUCTION}

The biological diversity of the Tien Shan and Pamir mountains is extremely interesting and unique, but unfortunately is still poorly investigated. Before the current investigations, only insufficient information on chironomids was possible to find throughout hydrobiological studies based essentially on larval material (Pankratova, 1950; Kurmangalieva, 1974; Akhrorov, 1975, 1988; Kustareva and Ivanova, 1980). On the basis of a first imagine and larval material collected during the eighties of the last century in rivers and streams of Tien Shan and Pamir mountains, one new genus of Podonominae (Shilovia) and six species belonging to three genera of the subfamily Diamesinae (including three undescribed species) were found (Makarchenko and Bulgakov, 1986; Makarchenko, 1989a-b; Makarchenko and Kobayashi, 1997; Makarchenko and Makarchenko, 2000). Some years later, additional taxonomic and systematics studies on the Diamesinae subfamily have been implemented on this important area of the Palaearctic Region. Based on a large fieldwork accumulated since 2000 by Dr. Dmitry Palatov (Moscow State University) who travelled along the Pamir and Tien Shan Regions, a material composed of adults, pupae and larvae of Diamesinae have been examined using morphological studies and DNA barcoding allowed us to generate a list of 19 taxa/species: Boreoheptagyia sp., Boreoheptagyia sp. 1, Diamesa bertrami Edwards, D. cinerella Meigen, $D$. filicauda Tokunaga, $D$. hamaticornis Kieffer, D. khumbugelida Saether et Willassen, D. planistyla Reiss, Diamesa akhrorovi sp. nov., D. alibaevae sp. nov., $D$. steinboecki Goetghebuer, D. zelentzovi Makarchenko, D. zhiltzovae Makarchenko, Pagastia aff. lanceolata Tokunaga, Pagastia sp. 1 Makarchenko, Pagastia sp. 2, Pseudodiamesa sp. (gr. branickii), Pseudodiamesa sp. (gr. nivosa), and Shilovia rara Makarchenko (currently transferred to Diamesinae subfamily).

Molecular lower-level phylogenetic research and DNA barcoding within family Chironomidae is considered as a beneficial approach for resolving the taxonomic status and evolution of chironomids (Ekrem et al., 2007, 2010a, Montagna et al., 2016, Makarchenko et al., 2017). Multilocus approach using mitochondrial and nuclear markers showed its reliability for phylogenetic analysis (Ekrem et al., 2010a; Cranston, 2010, 2012).

In the present paper two new species of the genus Diamesa Meigen, 1835 are described based on material collected from Tien Shan and Pamir mountains: $D$. akhrorovi sp. nov., as male adult; $D$. alibaevae sp. nov., 
as male adult and pupa. DNA barcoding results of the two new described species with comparative database on some related Diamesa species are also given. In addition, we used five commonly molecular markers COI, COII, 16S, $18 \mathrm{~S}$ and EF-1a for estimating phylogenetic relationships of the studied Diamesa species. Descriptions of other new species will be published in separate papers.

\section{METHODS}

The material was preserved in $96 \%$ ethanol for DNAanalysis and in 70\% ethanol for further study of morphology and slide-mounting, following the methods by Makarchenko (1985). The pupa and adult male were associated by using of DNA barcoding. The terminology follows Sæther (1980).

Holotypes and paratypes of the new species are deposited in the Federal Scientific Center of the East Asia Terrestrial Biodiversity, Far East Branch of the Russian Academy of Sciences, Vladivostok, Russia (FSCEATB FEB RAS).

Total genomic DNA was extracted from thorax of the 27 individual specimens of chironomids using the Invitrogen PureLink Genomic DNA Mini Kit in compliance with the manufacturer's protocols. Primers for PCR amplification on three mitochondrial and two nuclear markers given in Tab. S1. The PCR conditions and thermal regime given in Makarchenko et al. (2017), but the elongation time varied in accordance with the length of the amplicons. The PCR products were bidirectionally sequenced using the BigDye Terminator v3.1 cycle kit and run on an ABI 3130xl (Applied Biosystems ${ }^{\mathrm{TM}}$ ). Sequences were manually assembled and edited using Finch TV and MEGA 7 (Kumar et al., 2016). The obtained sequences were checked aligned at the nucleotide level using MUSCLE (Edgar, 2004). The obtained alignment has one gap in 18S rRNA. To estimation the Kimura 2 parameter (K2P) distances we use MEGA 7 (Kumar et al., 2016).

Bayesian phylogenetic analyses were conducted with MrBayes v. 3.2.6 (Ronquist and Huelsenbeck, 2003). PartitionFinder 2.1.1 (Lanfear et al., 2012) was used to select the best-fit partitioning scheme and models separately for each codon position of protein coding genes as well as ribosomal loci using the greedy algorithm with linked branch lengths for the corrected Akaike Information Criterion as the optimality criterion for model selection. The best models for partitions given in Tab. S2. For the protein coding markers (COI, COII, EF-1a), we were convinced that there was no influence for the tree topology by saturation in third codon positions. The constructed NJ trees for 5 markers did not reveal a significant contradiction with the final tree.

Bayesian Inference was performed with two independent runs of Metropolis-coupled Markov chain Monte Carlo analyses, with each run comprising one cold chain and three heated chains at a default temperature of 0.1 . The chains were run for 10 million generations and sampled every 100 generations. A burn-in of 100000 generations (or $1 \%$ of the sampled trees) was used. Moreover, trace files were visually inspected in Tracer 1.7 (Rambaut et al., 2018). All the obtained sequences of chironomids given in Tab. S3.

\section{DESCRIPTIONS}

\section{Diamesa planistyla Reiss}

(Fig. 1 A,C,F,G).

Diamesa planistyla Reiss, 1968: 57, Fig. 2; Serra-Tosio, 1983:17.

Material. Five adult males, Kirgizstan, Chuy Region, Alamudun district, Tien Shan Mountains, Kirghiz Range, Adygene River, altitude $2109 \mathrm{~m}$ above sea level, 29.V.2016, N 42³4.247', E 74²8.649', leg. D. Palatov; 2 adult males, the same data, except for left tributary of the Ala-Archa River, 29.05.2016, leg. D. Palatov; 1 adult male, Xinjiang Uygur Autonomous Region of the Republic of China, Tien Shan Mountains, Bogdo-Ula Range, Zienzan River, altitude $2443 \mathrm{~m}$ above sea level,

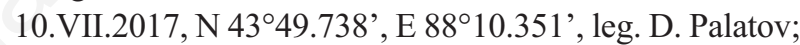
1 adult male, the same data except for Urumqi City District, Sangecha River, altitude $2356 \mathrm{~m}$ above sea level, 13.VII.2017, N 4340.583', E 88 17.006', leg. D. Palatov.

Remarks. D. planistyla Reiss was described by Reiss (1968) from the Himalayas based on a single male specimen which did not have antennae. Later, Serra-Tosio (1983) redescribed this species from the same area on two male specimens, specifying that the antennae were with numerous but shortened setae, and gonostylus had only one, but not two, preapical megaseta. Also, the author noted that the preapical part of the gonostylus had a dark sclerotized protrusion. Serra-Tosio believed that a gonostylus with two megaseta is an aberration. We do not hold this opinion, because all males collected from the Tien Shan, which we refer to $D$. planistyla, have gonostylus with two megaseta, as in the description of Reiss (1968).

Comparing the Reiss and Serra-Tosio descriptions with our data on $D$. planistyla and new species close to it, we had concluded that Serra-Tosio most likely dealt with the one of new species we found. After receiving additional material from the Himalayas in the near future, we hope to solve the arisen taxonomic problem both at the morphological and molecular-genetic levels.

Taking in consideration the above data, we found it expedient to give the redescription of $D$. planistyla male according to our material.

Adult male $(\mathrm{n}=4)$. Total length: $3.6-4.3 \mathrm{~mm}$. Total length/wing length $0.97-1.16$. Colouration: body and legs brown to dark brown; wings grey to dark grey. 
Head. Eyes reniform, hairy; macrotrichiae 16-20 $\mu \mathrm{m}$ long, protruding beyond facets. Temporal setae including (from one side): 2 coronals, 3-4 frontals, 12-13 orbitals, 6-12 verticals and 2-6 postorbitals. Clypeus with 4-6 setae. Antenna with 13 flagellomeres, developed or little reduced plume (Fig. $1 \mathrm{~A}$ ); basal part of flagellomeres 112 and last flagellomere covered with setae 116-316 $\mu \mathrm{m}$ long and 48-168 $\mu \mathrm{m}$ long respectively; apex of ultimate flagellomere with 3-3 setae 20-28 $\mu \mathrm{m}$ long. Length (in $\mu \mathrm{m})$ of flagellomeres 1-13: 86-104, 36-40, 40-48, 36-48, 40-44, 36-44, 40-52, 48-52, 52-64, 40-52, 44-64, 40-64, 500-648; AR 0.94-1.02. Length (in $\mu \mathrm{m}$ ) of palpomeres $1-5$ : $32-44,84-140,148-208,116-132,64-204 ; 3^{\text {rd }}$ palpomere with sensilla capitata, diameter of $18-20 \mu \mathrm{m}$. Length of flagellomeres 1-13 /length of palpomeres 1-5: 1.81-1.86. Head width/palpomeres 1-5 length: 0.86-1.29.
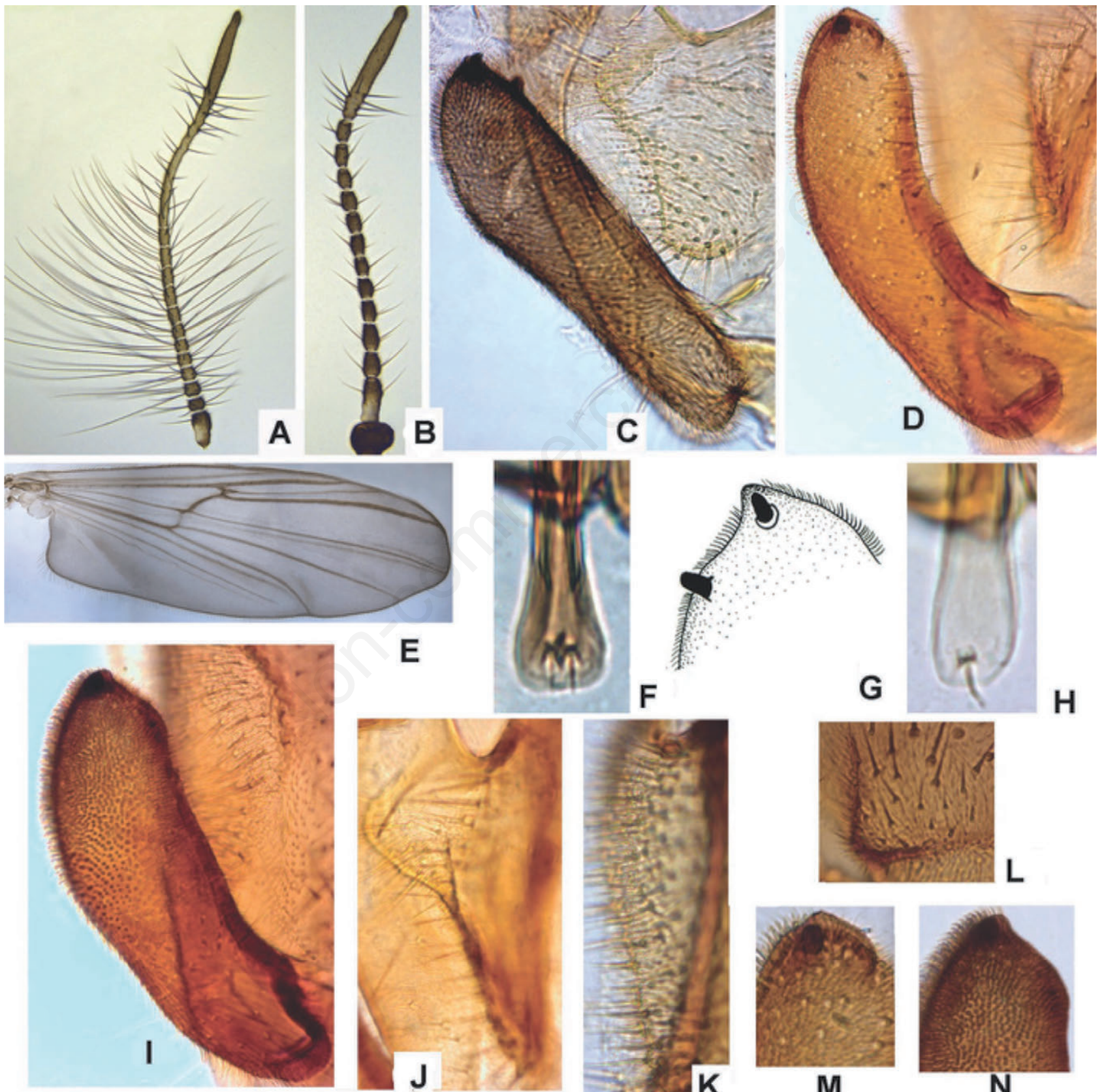

E
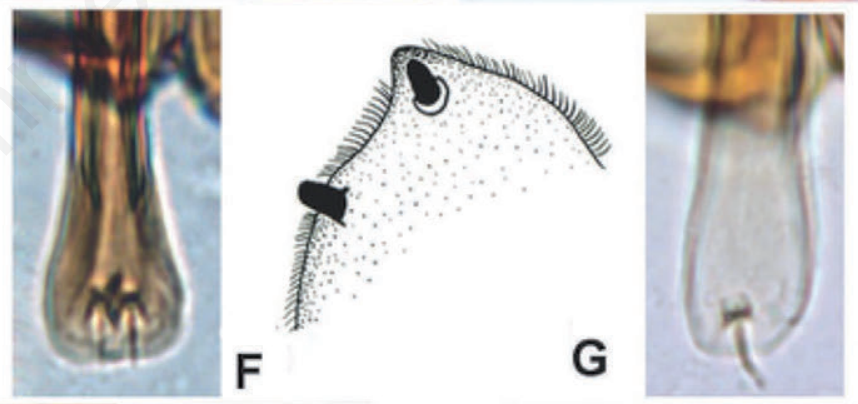

$\mathrm{H}$
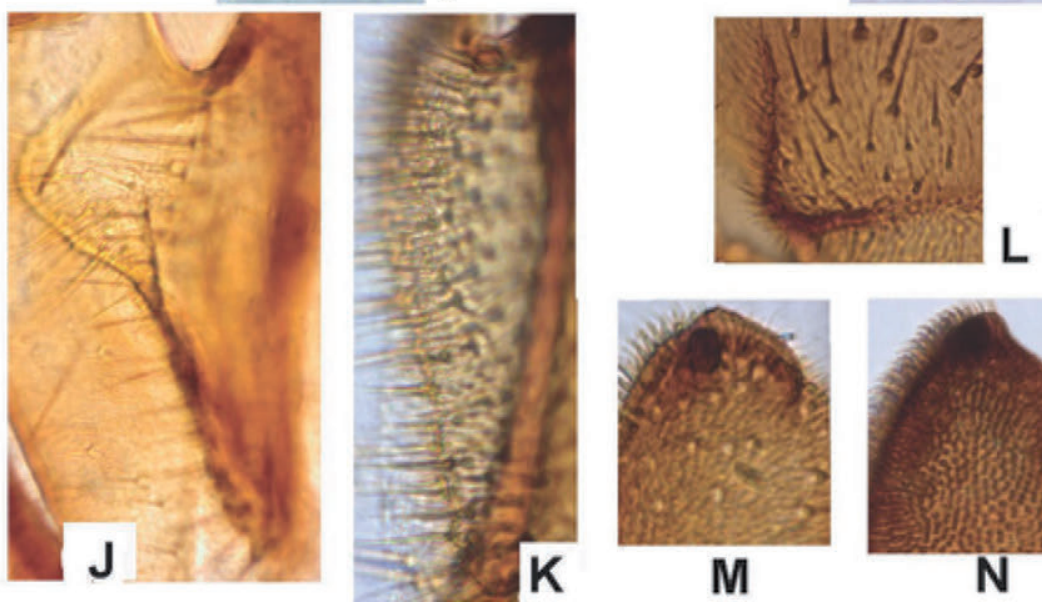

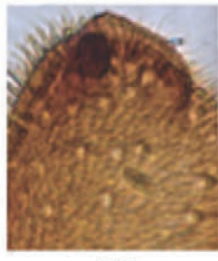

M

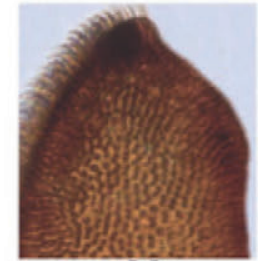

$\mathbf{N}$

Fig. 1. Adult male of Diamesa planistyla Reiss (A,C,F,G), Diamesa akhrorovi sp. nov. (B,D,E,J,M) and D. alibaevae sp. nov. (H,I,K,L,N). A,B) antenna; C,D,I) gonostylus; E) wing; F,H) terminal setae of anal point; G) apical part of gonostylus; J,K) inferior volsellae; L) angular protuberance of gonocoxite; $\mathrm{M}, \mathrm{N}$ ) distal part of gonostylus. 
Thorax. Antepronotum with 6-8 lateral setae; dorsocentrals 9-12; prealars 5-6; scutellars 16-18 (in 2 rows).

Wing. Length 3.3-3.9 mm, width 1.0-1.2 mm. R and $\mathrm{R}_{1}$ with 20-35 setae, $\mathrm{R}_{4+5}$ with 6-10. Length $\mathrm{RM} /$ length $\mathrm{MCu}: 2.6-2.8$. Anal lobe little reduced, truncated. Squama with 23-30 setae.

Legs. $\mathrm{BR}_{1} 1.9-2.6, \mathrm{BR}_{2}$ 1.4-2.0, $\mathrm{BR}_{3}$ 1.8-2.0. Spur of fore tibia $64-80 \mu \mathrm{m}$, spurs of middle tibia $48 \mu \mathrm{m}$ and 48 $60 \mu \mathrm{m}$, spurs of hind tibia 52-60 $\mu \mathrm{m}$ and 72-100 $\mu \mathrm{m}$ long. Hind tibial comb composed of 16 setae. Pulvilli absent. Claws falcated, with pointed apex. Lengths and proportions of leg segments as in Tab. 1.

Hypopygium (Fig. 1 C,F,G). Tergite IX semicircular, posterior margin distinctly bilobed on each side of the anal point; presence of 6-13 setae. Laterosternite IX with 1-4 short setae. Anal point 120-160 $\mu \mathrm{m}$ long (free distal part), long drop-like to pear-shaped distally, apex with 1-2 thin terminal setae 8-10 $\mu \mathrm{m}$ long (Fig. 1F). Sternapodeme lineararly extended transversally in its oral part; strongly projecting orally to form a pointed triangle-like expansion in its median part, 92-120 $\mu \mathrm{m}$ height. Phallapodeme consists of a large plate as figured in description of Reiss (1968, Fig. 2). Gonocoxite 420-574 $\mu \mathrm{m}$ long. Superior volsella small blade-like, covered with short setae. Inferior volsella consists of 2 distinct dorsal lobes: proximal one rounded to lobe-like, distal one elongated downwards and tapering distally. Gonostylus 260-304 $\mu \mathrm{m}$ long, uniformly elongated and straight; with two megasetae 8-12 $\mu \mathrm{m}$ long, one of which placed preapically and second located proximally at distance of $28-80 \mu \mathrm{m}$ and close to the inner edge (Fig. 1 C,G; Reiss, 1968, Fig. 2). HR 1.47-1.75.

Pupa and larva unknown.

Distribution. The species is known from the Himalayas and the Tien Shan.

\section{Diamesa akhrorovi Makarchenko et Semenchenko, sp. nov.}

(Fig. 1 B,D,E,J,M; Fig. 2 A,B).

Material. Holotype: adult male, Middle Asia, Tajikistan, Gorno-Badakhshan Autonomous Region, Shughnon District, Pamir Mountains, Maisara River near of Maisara Pass, 01.VII.2016, N 37²8.981', E $72^{\circ} 38.348^{\prime}$, leg. D. Palatov. Paratypes: 1 adult male, the same data as holotype.

Etymology. The new species is named in honour and memory of the Tajik hydrobiologist and researcher of the of chironomid fauna of Pamir Dr. Feruz Akhrorov.

Adult male $(n=2)$. Total length: $3.7 \mathrm{~mm}$. Total length/wing length 1.09. Colouration: body largely brown to dark brown; wings grey to dark grey; femur of all legs brown yellowish, tibia and tarsus light brown.

Head. Eyes reniform, hairy; macrotrichiae 16-20 $\mu \mathrm{m}$ long, protruding beyond facets. Temporal setae including (from one side): 2 coronals, 3-4 frontals, 12-13 orbitals, 12 verticals and 2 postorbitals. Clypeus with 8-9 setae. Antenna with 13 flagellomeres and reduced plume (Fig. 1B); basal part of flagellomeres 1-12 and last flagellomere covered with short setae 56-92 $\mu \mathrm{m}$ long and 72-132 $\mu \mathrm{m}$ long respectively; apex of ultimate flagellomere with 6 setae 20-44 $\mu \mathrm{m}$ long. Length (in $\mu \mathrm{m}$ ) of flagellomeres: $140,56,60,60,60,52,60,52,62,52,64,54,280$; AR 0.36 . Length (in $\mu \mathrm{m}$ ) of palpomeres $1-5: 52,96,160,124$, $164 ; 3^{\text {rd }}$ palpomere with sensilla capitata, diameter of 24 $\mu \mathrm{m}$. Length of flagellomeres 1-13/length of palpomeres 1-5: 1.77. Head width/palpomeres 1-5 length: 0.97.

Thorax. Antepronotum with 4-5 lateral setae; dorsocentrals 8; prealars 4-5; scutellars 12-14.

Wing (Fig. 1E). Length $3.42 \mathrm{~mm}$, width $0.8 \mathrm{~mm}$. R and $\mathrm{R}_{1}$ with 36 setae, $\mathrm{R}_{4+5}$ with 22 . Length $\mathrm{RM} /$ length $\mathrm{MCu}: 2.8$. Anal lobe little reduced, truncated. Squama with 16 setae.

Legs. Spur of fore tibia $56 \mu \mathrm{m}$, spurs of middle tibia $60 \mu \mathrm{m}$ both, spurs of hind tibia $60 \mu \mathrm{m}$ and $94 \mu \mathrm{m}$ long. Hind tibial comb composed of 17 setae. Fore leg with 12 apical pseudospurs on $\mathrm{ta}_{1}$; mid and hind legs with 9-10 pseudospurs on $\mathrm{ta}_{1} ; \mathrm{ta}_{4}$ cylindrical. Pulvilli absent. Claws falcated, with pointed apex. Lengths and proportions of leg segments as in Tab. 2.

Hypopygium (Fig. 1 D,J; Fig. 2 A,B). Tergite IX semicircular, slightly narrowing distally, posterior margin distinctly bilobed on each side of the anal point; presence of 20-23 setae placed on both median and posterior areas, setae located along the posterior margin are longer. Laterosternite IX with 2 short setae. Anal point $192 \mu \mathrm{m}$ long (free distal part), long drop-like to pear-shaped distally, apex with 1-2 terminal setae 8-9 $\mu \mathrm{m}$ long and 3$4 \mu \mathrm{m}$ wide (Fig. 2B). Sternapodeme lineararly extended transversally in its oral part; strongly projecting orally to

Tab. 1. Lengths (in $\mu \mathrm{m})$ and proportions of leg segments of male Diamesa planistyla Reiss $(\mathrm{n}=4)$.

\begin{tabular}{|c|c|c|c|c|c|c|c|c|c|c|}
\hline & fe & ti & $\mathrm{ta}_{1}$ & $\mathrm{ta}_{2}$ & $\mathrm{ta}_{3}$ & $\mathrm{ta}_{4}$ & $\mathrm{ta}_{5}$ & LR & $\mathbf{B V}$ & SV \\
\hline P1 & $1443-1960$ & 1509-1960 & $1017-1360$ & $508-720$ & $312-480$ & $80-82$ & $131-160$ & $0.67-0.70$ & $3.67-3.84$ & $2.81-2.90$ \\
\hline $\mathrm{P} 2$ & $1542-2040$ & $1279-1760$ & $656-840$ & $328-460$ & $213-280$ & $80-82$ & $131-160$ & $0.48-0.51$ & $4.61-4.73$ & $4.20-4.52$ \\
\hline P3 & $1680-2160$ & $1560-2100$ & $1200-1440$ & $640-840$ & $320-480$ & $80-120$ & 160 & $0.67-0.77$ & $3.56-3.85$ & $2.70-3.10$ \\
\hline
\end{tabular}



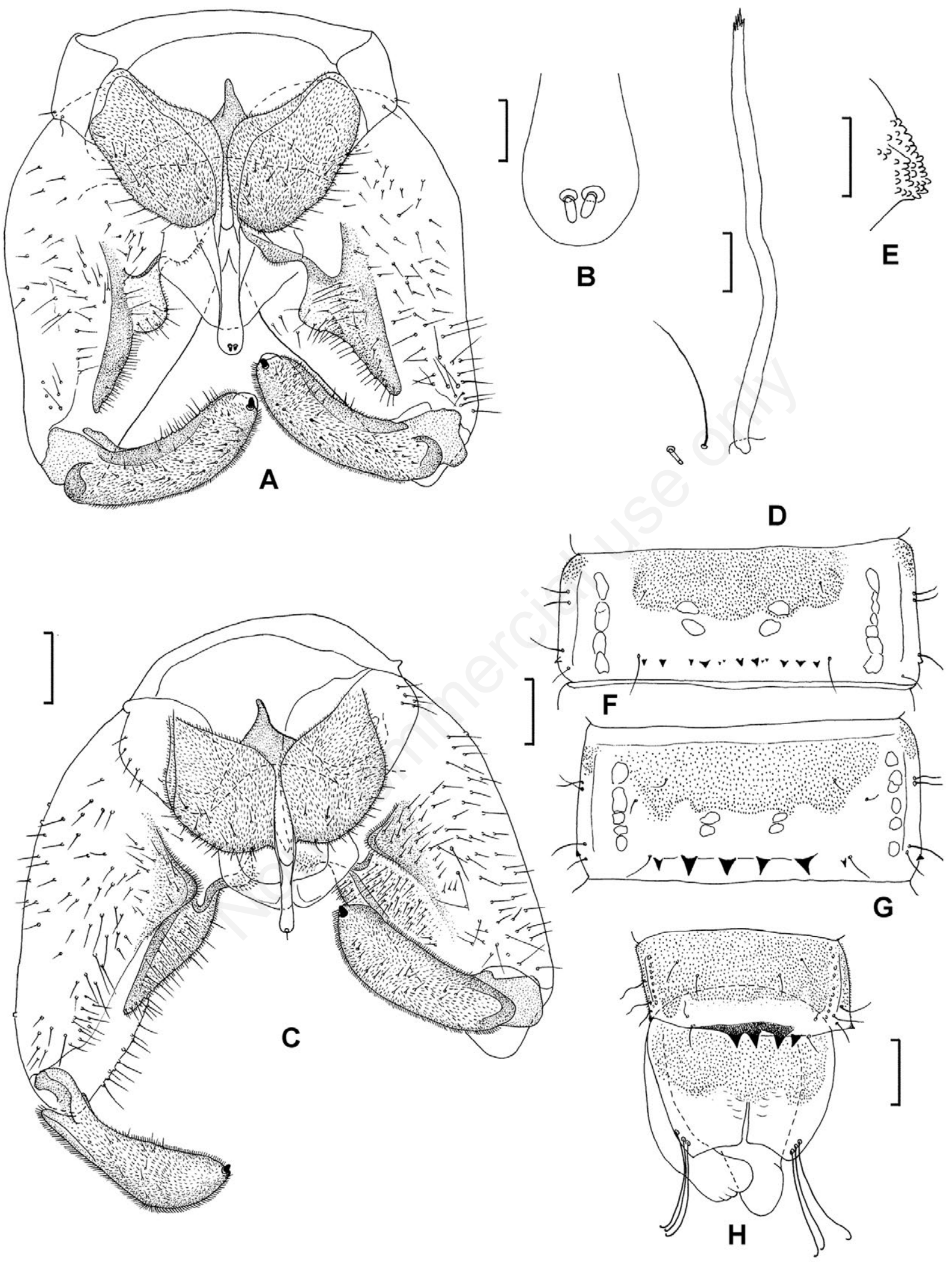

Fig. 2. Adult male (A-C) and pupa (D-H) of Diamesa akhrorovi sp. nov. (A,B) and D. alibaevae sp. nov. (C-H). A,C) hypopygium in dorsal view; B) terminal setae of anal point; D) thoracic horn and precorneals; E) basal part of antennal case; F) tergite II; G) tergite IV; H) tergite VIII and anal segment. Scale bars: A,C) $100 \mu \mathrm{m}$; B) $20 \mu \mathrm{m}$; D,E) $50 \mu \mathrm{m}$; F-H) $200 \mu \mathrm{m}$. 
form a pointed triangle-like expansion in its median part. Phallapodeme consists of a large plate as in D. planistyla. Gonocoxite $590 \mu \mathrm{m}$ long. Superior volsella small bladelike, covered with short setae. Inferior volsella $312 \mu \mathrm{m}$ long, consists of 2 distinct dorsal lobes: proximal one rounded to lobe-like, distal one elongated downwards and tapering distally; basal lobe covered with few thick setae, distal lobe densely covered with long thin setae (Fig. 1J; Fig. 2A). Gonostylus (Fig. 1 D,M; Fig. 2A) 288-316 $\mu \mathrm{m}$ long, uniformly elongated and slightly curved medially; apical part with a characteristic sclerotized hyaline and bare plate of $28 \mu \mathrm{m}$ long, placed close to the megaseta; preapical megaseta $14 \mu \mathrm{m}$ long and strong. HR 1.89-2.05.

Pupa and larva unknown.

Diagnosic characters. D. akhrorovi sp. nov., is very closely related to $D$. planistyla Reiss and D. alibaevae sp. nov. from which it be separated based on the following combination of characters highlighted in the given key below, and additional DNA barcoding results illustrated in Fig. 3.

Tab. 2. Lengths (in $\mu \mathrm{m}$ ) and proportions of leg segments of male Diamesa akhrorovi sp. nov. (n=1).

\begin{tabular}{|c|c|c|c|c|c|c|c|c|c|c|}
\hline & fe & ti & $\mathrm{ta}_{1}$ & $\mathrm{ta}_{2}$ & $\mathrm{ta}_{3}$ & $\mathrm{ta}_{4}$ & $\mathrm{ta}_{5}$ & LR & BV & SV \\
\hline $\mathrm{P} 1$ & 1960 & 1960 & 1300 & 640 & 400 & 140 & 200 & 0.66 & 3.78 & 3.02 \\
\hline $\mathrm{P} 2$ & 2000 & 1740 & 880 & 480 & 300 & 120 & 160 & 0.51 & 4.39 & 4.25 \\
\hline P3 & 2240 & 2120 & 1360 & 800 & 400 & 120 & 160 & 0.64 & 3.86 & 3.21 \\
\hline
\end{tabular}

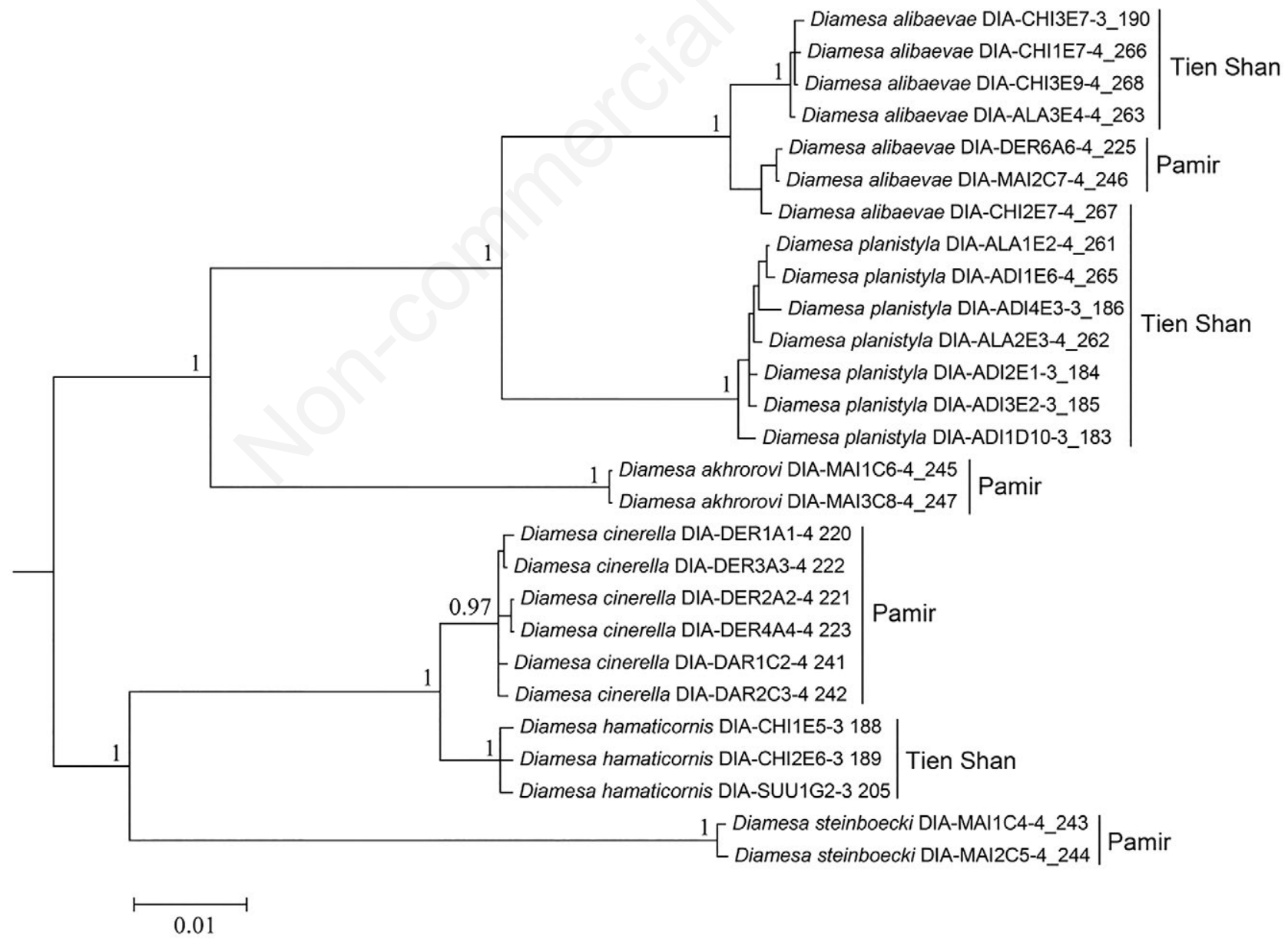

Fig. 3. Bayesian tree of the genus Diamesa Meigen from Tien Shan and Pamir on the mitochondrial COI, COII, 16S rRNA and nuclear $18 \mathrm{~S}$ rRNA, EF-1a sequences (3550 bp). Bayesian posterior probabilities (PP) given in tree nodes. 
Distribution. Known only from the type locality in Pamir Mountains.

\section{Diamesa alibaevae Makarchenko et Semenchenko, sp. nov.}

(Fig. 1 H,I,K,L; Fig. 2 C,H).

Material. Holotype: adult male, Middle Asia, Kirgizstan, Talas Region, Talas district, Tien Shan Mountains, Chychkan River, about 10-15 km below the pass of the Suusamyr Valley, 2.VI.2016, N 42 ${ }^{\circ} 11.937^{\prime}$, E $72^{\circ} 59.380^{\prime}$, leg. D. Palatov. Paratypes: 3 adult males, the same data as for holotype; 1 mature pupa, Kirgizstan, Chuy Region, Alamudun district, Tien Shan Mountains, Kirghiz Range, Adygene River (left tributary of the AlaArcha River), 28.V.2016, N 42³4.247', E 74²8.649', leg. D. Palatov; 1 adult male, Tajikistan, GornoBadakhshan Autonomous Region, Shughnon District, Pamir Mountains, Maisara River near of Maisara Pass, 01.VII.2016, N 37²8.981', E 72³8.348', leg. D. Palatov.

Etymology. The new species is named in honour of Dr. Munovar Alibaeva who was wife of Dr. F. Akhrorov and studied benthos of Pamir rivers and lakes.

Adult male $(\mathrm{n}=4)$. Total length: $3.5-3.7 \mathrm{~mm}$. Total length/wing length $0.97-1.1$. Colouration: body largely brown to dark brown; wings grey to dark grey; legs light brown to brown.

Head. Eyes reniform, hairy; macrotrichiae 16-24 $\mu \mathrm{m}$ long and protruding beyond facets. Temporal setae including (from one side): 2 coronals, 2-4 frontals, 5-14 orbitals, 5-9 verticals and 3-7 postorbitals. Clypeus with 46 setae. Antenna with 13 flagellomeres and reduced plume (as in D. akhrorovi sp. nov.); flagellomeres 1-12 66-132 $\mu \mathrm{m}$ long, covered with short setae 40-88 $\mu \mathrm{m}$ long in basal part; apex of ultimate flagellomere with 5-7 setae $18-40 \mu \mathrm{m}$ long. Length of flagellomeres 1-13 ( $\mu \mathrm{m})$ : 104-124, 48-60, 46-60, 44-52, 44-56, 40-50, 40-52, 44-50,44-68, 44-52, 46$52,36-48,244-288$; AR 0.36-0.43. Length of palpomeres $1-5(\mu \mathrm{m}): 44-60,92-116,152-184,100-124,124-144 ; 3^{\text {rd }}$ palpomere with sebsilla capitata diameter of $24-28 \mu \mathrm{m}$. Length of flagellomeres1-13/length of palpomeres 1-5: 1.58-1.63. Head width/palpomeres 1-5 length: 0.96-1.05.

Thorax. Antepronotum with 5 lateral setae; dorsocentrals 8; prealars 3; scutellars 16 .

Wing. Length 3.2-3.6 mm, width $0.88-1.12 \mathrm{~mm}$. R and $\mathrm{R}_{1}$ with $24-41$ setae, $\mathrm{R}_{4+5}$ with $12-17 ; \mathrm{Cu}_{2}$ occasionally with 1 seta in basal part. Length RM/length MCu: 2.0-2.7. Anal lobe little reduced, truncated. Squama with 11-20 setae.

Legs. Spur of fore tibia $56-80 \mu \mathrm{m}$, spurs of middle tibia 40-64 $\mu \mathrm{m}$ both, spurs of hind tibia $62-100 \mu \mathrm{m}$ and 96-108 $\mu \mathrm{m}$ long. Hind tibial comb composed of 14-20 setae. Fore leg with 2 apical pseudospurs on $\mathrm{ta}_{1}$; mid leg with 4-6 pseudospurs on $\mathrm{ta}_{1}$, hind leg with 6-10 pseudospurs on $\mathrm{ta}_{1} ; \mathrm{ta}_{4}$ cylindrical. Pulvilli absent. Claws falcated, with pointed apex. Length (in $\mu \mathrm{m}$ ) and proportions of legs as in Tab. 3.

Hypopygium (Fig. 1 H,I,K,L,N; Fig. 2C). Tergite IX broadly semicircular, posterior margin slightly bilobed on each side of the anal point; presence of 16-18 nearly subequal setae placed on both median and posterior areas. Laterosternite IX with 9-12 short setae. Anal point 132 $\mu \mathrm{m}$ long (free distal part), distal part long drop-like to pear-shaped; apex with 1 single thin terminal seta $12 \mu \mathrm{m}$ long (Fig. 1H; Fig. 2C). Sternapodeme and phallapodeme nearly as in $D$. akhrorovi sp. nov. Gonocoxite $582 \mu \mathrm{m}$ long, basal inner part with a characteristic angular protuberance (Fig. 1L). Superior volsella reduced. Inferior volsella $196 \mu \mathrm{m}$ long, unilobed, consists of a large lobelike with narrowed distal part, densely covered with thin setae (Fig. 1K; Fig. 2C). Gonostylus $328 \mu \mathrm{m}$ long, distal part broadened; inner subapical margin with a small bulge; megasetae $12 \mu \mathrm{m}$ long, tooth-like and placed apically (Fig. 1 I,N; Fig. 2C). HR 1.77.

Pupa $(\mathrm{n}=1)$. Total length $3.9 \mathrm{~mm}$. Colouration contrasting brown yellowish to dark brown.

Cephalothorax. Frontal apotome with 2 setae 160-172 $\mu \mathrm{m}$ long. Thorax granulated in both anterior and posterior parts, granulation are smooth and less dense in posterior area. Thoracic horn light yellow, filiform, $348 \mu \mathrm{m}$ long, with few small spines apically (Fig. 2D); length $(\mu \mathrm{m})$ of precorneal setae: $\mathrm{Pc}_{1}-104, \mathrm{Pc}_{2}-184$. Antepronotum with 3 antepronotals 17-24 $\mu \mathrm{m}$ long. Dorsocentrals $2180 \mu \mathrm{m}$ long. Base of antennal sheath distinctly granulated (Fig. 2E).

Abdomen. Tergite I bare. Tergites II-VIII with shagreen and field of spinules in both anterior and lateral parts; posteromedian transverse rows of strong horn-like thick spines present on tergites II-VIII; number of spines by tergite is respectively: $9,9,6,7,6,7,4$; size of triangle-like spines becoming gradually bigger from tergites II to VIII (Fig. 2F-H). Posteromedian rows of spines present only on sternites III-VIII; number of spines by sternite is respectively: 10, 10, 16, 14, 7, 9 . Spines on tergites almost twice as large as those on

Tab. 3. Lengths (in $\mu \mathrm{m}$ ) and proportions of leg segments of male Diamesa alibaevae sp. nov. (n=4).

\begin{tabular}{|c|c|c|c|c|c|c|c|c|c|c|}
\hline & $\mathrm{fe}$ & $\mathrm{ti}$ & $\mathrm{ta}_{1}$ & $\mathrm{ta}_{2}$ & $\mathrm{ta}_{3}$ & $\mathrm{ta}_{4}$ & $\mathrm{ta}_{5}$ & $\mathbf{L R}$ & BV & SV \\
\hline $\mathrm{P} 1$ & 1560-1920 & $1440-1920$ & $980-1240$ & $480-640$ & $280-500$ & 120 & 160 & $0.65-0.72$ & $3.43-3.85$ & $2.98-3,24$ \\
\hline $\mathrm{P} 2$ & $1640-2160$ & $1280-1680$ & $680-920$ & $320-460$ & $220-280$ & $80-120$ & $120-160$ & $0.53-0.56$ & $4.67-4.86$ & $4.10-4.33$ \\
\hline P3 & $1720-2200$ & $1560-1960$ & $1120-1400$ & $560-760$ & $320-400$ & $100-120$ & $120-160$ & $0.70-0.72$ & $3.68-3.93$ & 2.93-3.09 \\
\hline
\end{tabular}


sternites. Tergite IX with field of shagreen and spinules present on anterior half and laterally. Distribution of lateral setation on segments I-VII is as follows: I with 2 pairs of setae $60 \mu \mathrm{m}$ long, II-VII with 4 pairs; length of $\mathrm{LS}_{1}-\mathrm{LS}_{3} 88-136 \mu \mathrm{m}$. Segment VIII with 3 pairs of lateral setae 33-88 $\mu \mathrm{m}$ long, located as in Fig. 8; dorsal setae length $68-128 \mu \mathrm{m}$. Anal lobe with 3 needle-like macrosetae 216-260 $\mu \mathrm{m}$ long (Fig. 2H).

Larva unknown.

Diagnosic characters. D. alibaevae sp. nov. is keyed near both $D$. planistyla and $D$. akhrorovi sp. nov., from which it can be distinguished based on the combination of characters provided as well in the given key below and results of DNA barcoding illustrated in Fig. 3.

Distribution. Known only from the type locality in Tien Shan and Pamir Mountains.

Key to adult males of related known Diamesa species to D. planistyla Reiss

1. Antennal plume developed or little reduced (Fig. 1A). Gonostylus with two megasetae (one placed preapically and second located proximally close to the inner edge (Fig. 1 C,G; Reiss, 1968, Fig. 2). Anal point with 1-2 thin terminal setae (Fig. 1F) ... D. planistyla Reiss

- Antennal plume reduced (Fig. 1B). Gonostylus with only one terminal megaseta. Anal point with 1 thin or 1-2 thicker terminal setae ... 2

2. Inferior volsella consists of 2 lobes, from which proximal rounded, distal larger and elongated (Fig. 1J; Fig. 2A). Base of gonocoxite without a distinct protuberance. Gonostylus slightly curved medially, in subapical part with megasetae and chitinized naked plate (Fig. $1 \mathrm{D}, \mathrm{M})$. Anal point with 1-2 wide terminal setae (Fig. 2B) ... D. akhrorovi sp. nov.

- Inferior volsella unilobed, consists of only one large lobe (Fig. 1K; Fig. 2C). Base of gonocoxite with a distinct protuberance (Fig. 1L; Fig. 2C). Gonostylus slightly expanding in its distal part, with only 1 subapical megaseta and tooth, apical area with a slight bulge placed close to the megaseta (Fig. 1 I,N). Anal point with 1 thin terminal seta $($ Fig. $1 \mathrm{H})$... D. alibaevae sp. nov.

\section{RESULTS OF DNA BARCODING AND DISCUSSION}

The length of aligned sequences given in Tab. S1. Genetic marker COII contains complete COII sequence in front of which 41-42 bp of tRNA-Leu and finally 15-
$17 \mathrm{bp}$ of tRNA-Lys. The gene EF-1a in most Diamesa was $898 \mathrm{bp}$, but two specimens of D. steinboecki had an $81 \mathrm{bp}$ intron at the end of EF-1a marker. The tRNA sequences as well as intron in EF-1a were excluded from Bayesian analysis. A final multilocus dataset of $3550 \mathrm{bp}$, of which 302 were parsimony informative.

We used Bayesian phylogenetic analysis to present Diamesa relationships from Tien Shan and Pamir (Fig. 3). In the basis of the constructed tree, two sister groups were formed, $D$. cinerella $+D$. hamaticornis + $D$. steinboecki and D. alibaevae $+D$. planistyla $+D$. akhrorovi. Species D. cinerella $+D$. hamaticornis were close however monophyly of this groups was supported ( $\mathrm{PP}=1)$. Similarly, described species D. akhrorovi $\mathrm{sp}$. nov. and $D$. alibaevae sp. nov. united with $D$. planistyla formed a highly supported monophyletic groups $(\mathrm{PP}=1)$. Species D. alibaevae sp. nov. lives both in the Pamir and in the Tien Shan and has insignificant intraspecific variations.

Combining phylogenetic analysis and DNA barcoding allows to effectively species-level identification approach (Ekrem et al., 2007, 2010b; Montagna et al., 2016). For DNA barcoding, we used only 658 bp fragment of the mitochondrial gene cytochrome $\mathrm{c}$ oxidase I (COI) according to Hebert et al. (2003). The average interspecific genetic distance based on Kimura 2 parameter (K2P) model found in Tien Shan and Pamir species of the genus Diamesa was 0.095 which concordance to Montagna et al. (2016).

The K2P sequence divergence between Diamesa akhrorovi sp. nov. and other species of the genus Diamesa from Pamir and Tien Shan (D. alibaevae, D. cinerella, D. hamaticornis, D. planistyla) was 0.102 - 0.115 (Tab. S4). The species independence of $D$. alibaevae sp. nov. on $D$. planistyla determined by $0.083 \mathrm{~K} 2 \mathrm{P}$ sequence divergence. Distances between $D$. cinerella $+D$. hamaticornis was 0.023 which is at the lower level of species independence (Montagna et al., 2016). According to Montagna et al. (2016), D. cinerella and D. tonsa are closely related species and $D$. hamaticornis probably also includes to $D$. cinerella / D. tonsa.

\section{ACKNOWLEDGEMENTS}

We are much grateful to Joel Moubayed for useful discuss on Diamesa planistyla taxonomy and for translating the B. Serra-Tosio's paper from French to English.

\section{FUNDING}

This work was partly supported by the Russian Science Foundation (project No. 14-50-00034). 


\section{REFERENCES}

Akhrorov F, 1975. [New larval forms of midges (Diptera, Chironomidae) from the Kairak-Kum Reservoir].[Article in Russian]. Gidrobiol. Zh. 11: 6-71.

Akhrorov F, 1988. [Chironomid fauna of Pamir reservoirs]. [Article in Russian]. Izv. Akad. Nauk Respubl. Tadzhikistan. Biol. Otdel. 4:38-43.

Cranston PS, Hardy NB, Morse GE, Puslednik L, McCluen SR, 2010. When morphology and molecules concur: the 'Gondwanan' midges (Diptera: Chironomidae). Syst. Entomol. 35:636-648.

Cranston PS, Hardy NB, Morse GE, 2012. A dated molecular phylogeny for the Chironomidae (Diptera). Syst. Entomol. 37:172-188.

Edgar RC, 2004. MUSCLE: multiple sequence alignment with high accuracy and high throughput. Nucleic Acids Res. 32:792-1797.

Ekrem T, Willassen E, Stur E, 2007. A comprehensive DNA sequence library is essential for identification with DNA barcodes. Mol. Phylogenet. Evol. 43:530-542.

Ekrem T, Stur E, Hebert PDN, 2010a. Females do count: Documenting Chironomidae (Diptera) species diversity using DNA barcoding. Org. Divers. Evol. 10:397.

Ekrem T, Willassen E, Stur E, 2010b. Phylogenetic utility of five genes for dipteran phylogeny: a test case in the Chironomidae leads to generic synonymies. Mol. Phylogenet. Evol. 57: 561-571.

Kumar S, Stecher G, Tamura K, 2016. MEGA7: Molecular evolutionary genetics analysis, ver. 7.0 for bigger datasets. Mol. Biol. Evol. 33: 870-4.

Hebert PDN, Cywinska A, Ball SL, de Waard JR, 2003. Biological identifications through DNA barcodes. P. R. Soc. Lond. 270:313-321.

Kurmangalieva ShG, 1974. [To the fauna of larvae of chironomids (Chironomidae, Orthocladiinae) of Turgen' River (Zailiiskii Alatau)].[Article in Russian]. Biol. Sci. Kazahskyi University publisher, Alma-Ata 6:52-55.

Kustareva LA, Ivanova LM, 1980. [Benthos of the Issyk-Kul Lake tributaries].[Article in Russian]. Ilim, Frunze: 103 pp.

Makarchenko EA, 1985. [Chironomids of the Soviet Far East. Subfamilies Podonominae, Diamesinae and Prodiamesinae (Diptera, Chironomidae)].[Article in Russian]. DVNC AN SSSR Press, Vladivostok: 208 pp.
Makarchenko EA, Bulgakov GP, 1986. [A new species of Diamesa Mg. (Diptera, Chironomidae) from Uzbekistan]. [Article in Russian]. Biol. Vnutr. Vod. 70:37-42.

Makarchenko EA, 1989a. [A new and a little known species of the genus Diamesa (Diptera, Chironomidae) from Tadjikistan].[Article in Russian]. Vestn. Zool. 2:82-85.

Makarchenko EA, 1989b. [New genus and species of chironomids (Diptera, Chironomidae) from Tajikistan]. [Article in Russian]. Zool. Zh. 68:137-142.

Makarchenko EA, Kobayashi T, 1997. Diamesa amanoi sp. n., a new species of Diamesinae (Diptera, Chironomidae) from Nepal, with notes on taxonomy and distribution of some Diamesa Meigen. Med. Ent. Zool. 48:45-48.

Makarchenko EA, Makarchenko MA, 2000. Revision of Pagastia Oliver, 1959 (Diptera, Chironomidae) of the Holarctic region, p. 171-176. In: O. Hoffrichter (ed.), Late 20th Century Research on Chironomidae: An Anthology from the 13th Int. Symp. on Chironomidae. Shaker Verl. Aachen.

Makarchenko EA, Makarchenko MA, Semenchenko AA, 2017. New or little-known species of Chaetocladius s. str. Kieffer, 1911 (Diptera: Chironomidae: Orthocladiinae) from the Amur River basin (Russian Far East). Zootaxa 4247:313-330.

Montagna M, Mereghetti V, Lencioni V, Rossaro B, 2016. Integrated taxonomy and DNA barcoding of Alpine midges (Diptera: Chironomidae). PLoS One 11:e0149673.

Pankratova VY, 1950. [Fauna of larvae of the family Tendipedidae of Amu-Darya basin].[Article in Russian]. Trudy Zool. Inst. Akad. Nauk SSSR 9:116-198.

Rambaut A, Drummond AJ, Xie D, Baele G, Suchard MA, 2018. Posterior summarisation in Bayesian phylogenetics using Tracer 1.7. Syst. Biol. doi:10.1093/sysbio/syy032. [Epub ahead of print].

Reiss F, 1968. [Neue Chironomiden-Arten (Diptera) aus Nepal].[Article in German]. Khumbu Himal. 3:55-73.

Ronquist F, Huelsenbeck JP, 2003. MrBayes 3: Bayesian phylogenetic inference under mixed models. Bioinformatics 19:1572-1574.

Sæther OA, 1980. Glossary of chironomid morphology terminology (Chironomidae, Diptera). Entomol. Scand. Suppl. 14:1-51.

Serra-Tosio B, 1983. [Nouveaux Diamesinae de la Paléarctide méridionale et orientale (Diptera, Chironomidae].[Article in French]. Spixiana 6:1-26. 